\title{
Research on Foreign Ownership Applied in R\&D Investment of Chinese GEM Companies
}

\author{
Ying Wang ${ }^{1}$ \\ ${ }^{1}$ School of Finance, Jinan University, Guangzhou, China \\ Correspondence: Ying Wang, School of Finance, Jinan University, Guangzhou, China.
}

Received: March 13, 2017

Accepted: March 24, 2017

Online Published: April 7, 2017

doi:10.20849/ajsss.v2i1.139

URL: https://doi.org/10.20849/ajsss.v2i1.139

\begin{abstract}
This paper is to explore that if foreign ownership exactly affects on R\&D investment of Chinese GEM companies. We use six variables, including RDS (the ratio of R\&D and operating income), the proportion of foreign ownership, company size (the logarithm of total assets), gearing ratio, the proportion of the top five shareholders, and the location, to construct the regression model to verify the impact of foreign ownership on R\&D investment for 153 listed firm sample during 2009-2014, which has removed companies without R\&D investment. We find that foreign ownership and enterprise R\&D investment indeed exists positive correlation, but not significantly; further investigation found that foreign ownership will not improve enterprise performance when it promotes R\&D investment, but exist a negative correlation relationship. Therefore, such a relationship is important for company to control the proportion of foreign ownership to manage the ownership structure.
\end{abstract}

Keywords: foreign ownership, $R \& D$ investment, enterprise performance

\section{Introduction}

In the increasing globalization of world economy, there exists close relationship between nations, which has caused many countries to focus the capital flow between countries, especially the developing countries. After the reform and opening up policy, many foreign capital inflows into china, causing the great improvement in economy.

SMEs (small and medium enterprises) are the most dynamic, the largest number group in Chinese economy, which can not only promote development of Chinese economy, increase state revenue, provide a lot of job opportunities, but also can promote innovation of Chinese economy. However, compared with large enterprises, SMEs still have many drawbacks, such as small scale, short life cycle, and poor financing, which has restricted so many innovation activities that will hinder the innovation capacity of SMEs.

However, the introduction of foreign investors can give some relief to this problem. On the one hand, it can bring advanced technology and management experience of enterprises, and promote innovation activities to enhance innovation capacity; on the other hand, it can also promote the internationalization of Chinese enterprises.

Therefore, the research on foreign ownership applied in R\&D investment is particularly important, especially the SMEs. Whether foreign ownership can improve the R\&D investment of the SMEs? This study selects 153 firm samples listed in GEM during 2009-2014 to construct the regression model to verify the impact of foreign ownership on R\&D investment.

This article is organized as follows. It starts with a review of the literature on these topics. Next, it does empirical research, followed by the analysis and hypothesis. In the last, it describes implications for managers.

\section{Literature Review}

R\&D capability and marketing capability are two important capabilities of technology innovation. (Yao, Q., Xu, M., Jiang, W. F., \& Zhang, Y., 2014, pp.101-108) The introduction of foreign direct investors can stimulate the R\&D investment, and enhance the ability to innovate, while the relationship between foreign indirect investment and R\&D investment is not significant. The impact is the greatest when the foreign ownership reaches $10 \%$. (Ye, D. Z., \& Liu, S. B., 2015, pp.126-142) There are few research about the relationship between foreign ownership and the R\&D investment but a lot study about the foreign ownership and other aspects.

Studies about the relationship between foreign ownership and enterprises' performance have different 
perspective. Some empirical evidence shows that there is a negative correlation between foreign ownership and Tobin's Q, which indicates that the higher the foreign ownership, the worse the performance of the company, while there is a positive correlation between the nature of the foreign shareholders and the enterprises' performance. (Chen, L., 2011) A year after foreign mergers and acquisitions, three financial indicators (ROE, the main business revenue growth and liquidity ratios) appear declining trend, compared with a year before foreign mergers and acquisitions. (Zhang, B. H., 2007, pp.109-111)

In addition, corporate with high level of management can introduce more foreign investors, and the foreign shareholding ratio is negatively correlated with equity concentration, but positively correlated with the level of corporate governance. (Joon, K., Jiyeon, E. K., Wi, S. K., \& Suk, J. B., 2010, pp.390-420)

In the enterprise value theory, foreign investors can bring advanced technology and management experience for the enterprises to enhance the business performance, thereby enhance the value of the enterprises. (Manoranjan, P., 2007, pp.1459-1467) And the companies with foreign investors will pay more attention to information disclosure, compared with companies without foreign investment. Small companies will be more sensitive to the foreign investment and will improve a lot in the value of the company with respect to large firms. (Qu, L. Q., \& Wang, H. L., 2007, pp.51-54)

But other studies show that foreign ownership can positively affect the $\mathrm{PB}$, and has a positive relationship between foreign ownership and ROA, Tobin's Q; besides, it can improve profitability and operating performance. (Megginson, W. L., 2005, pp.1931-1980; Sun, Q., Tong, \& Wilson H. S., 2003, pp.183-222; Lei, J., 2012) As for the private listed companies, foreign investment can contribute to increase the value of private listed companies; and compared with companies that foreign investors are industrial legal entities and individuals, the companies that foreign investors are QFII investors can be more affected especially the performance. (Shieifer, A., \& Vishny, R. W., 1986, pp.401-488)

From the angle of financial value and return value, the introduction of foreign investors cannot improve corporate financial performance. When the business performance decreases, foreign investors with high proportion will take over their own shares by outside investors to achieve the investment value, and on the other hand, will cause certain enterprise management constraints. (Shieifer, A., \& Vishny, R. W., 1997; Wang, Y. M., 2009, pp.138-143; Jensen, M. C., \& Mechling, W. H., 1976, pp.305-360)

Based on the related research, this study provides a comprehensive analysis of the relationship between foreign ownership and R\&D investment of Chinese GEM companies. We hope the implication of the study is beneficial to the development of R\&D investment of GEM companies in China.

\section{Theoretical Analysis and Research Hypothesis}

The innovation activities of the enterprises will be constrained by many factors, such as capital constraints, the issue of corporate incentives, and constraints on their own. However, the introduction of foreign investment can get some relief on these constraints, so as to promote innovation of enterprises.

First, overseas holdings can provide financing support for SMEs. The most direct impact of the entry of foreign ownership is to provide funds for enterprises. When there are innovation activities, these funds will give a little relief to the constraints on innovation funds, while at the same time, it can form a capital market-oriented role, guiding other capital to enter enterprise.

Second, foreign ownership can provide directions on innovation. With respect to improved countries, the level of innovation of china is still in a low level, which means the introduction of foreign investors is strategically significant for Chinese enterprises. They can combine the foreign advanced technology with Chinese enterprises to guide the innovation.

Last, foreign ownership can provide risk pricing valuation for SMEs. Foreign investors have many successful innovative experiences in their countries, which can provide objective assessment of innovations according to their successful experiences while investing in China SMEs, better promoting innovation.

Therefore, based on the above analysis, this paper proposes one hypothesis: foreign ownership can positively increase R\&D investment, and therefore promote business innovation.

\section{Empirical Research}

\subsection{Variables and Models Design}

R\&D investment will be affected by other factors, such as company size, gearing ratio, the proportion of the top five shareholders, the location, and so on. In order to better research the impact of the foreign ownership on the $\mathrm{R} \& \mathrm{D}$ investment, some relevant factors have to be controlled. Therefore, we establish the following regression 
equation:

$$
\mathrm{RDS}=\alpha_{0}+\alpha_{1} \times \mathrm{FO}+\alpha_{2} \times \mathrm{SIZE}+\alpha_{3} \times \mathrm{ALR}+\alpha_{4} \times \mathrm{H}+\alpha_{5} \times \mathrm{IND}+\varepsilon
$$

Where:

$\mathrm{RDS}=$ the ratio of $\mathrm{R} \& \mathrm{D}$ expenses to operating income;

$\mathrm{FO}=$ the proportion of foreign ownership;

Size=logarithm of total assets;

$\mathrm{ALR}=$ the ratio of debt to total assets;

$\mathrm{H}=$ the proportion of the top five shareholders;

$\mathrm{IND}=\mathrm{a}$ dummy variable that equals 1 if the firm is located in the eastern region, and 0 otherwise.

\subsection{Data Collection}

We conduct our analysis with the companies which listed on the GEM from 2009-2014 period, and exclude companies with no foreign ownership.

Based on above criteria, we extract 153 sample observations for our analyses. We use CNINFO and CSMAR data sources to collect the data required. These databases are used to collect the corporate governance data and the accounting data.

\subsection{Summary Statistics}

Table 1 provides some summary statistics for the above variables. As revealed, among the companies that introduce foreign investment, the mean of the $R \& D$ investment is $6.33 \%$, the minimum is $0.44 \%$, which indicates that overall $R \& D$ investment is not great, and enterprises differs greatly.

The number of ROA is from -0.12 to 4.45 , the average is 0.14 , which means some corporate profitability is negative, and overall, corporate profitability is poor. The average of the proportion of foreign ownership is 24.54\%, a high level. But companies still differs a lot.

Table 1. Descriptive statistics of dependent and independent variables

\begin{tabular}{cccccc}
\hline Variables & Number & Min & Max & Mean & SD \\
\hline RDS & 153 & 0.0044247 & 0.2531 & 0.0632788 & 0.0478049 \\
FO & 153 & 0.0001 & 0.739 & 0.2453567 & 0.1735125 \\
H & 153 & 0.3266 & 0.8795 & 0.650551 & 0.1057999 \\
SIZE & 153 & 10.6009 & 13.088217 & 11.598092 & 0.5401827 \\
ALR & 153 & 0.0202752 & 0.6947039 & 0.2142872 & 0.1518362 \\
ROA & 153 & -0.1175 & 4.45 & 0.1424232 & 0.5395516 \\
IND & 153 & 0 & 1 & 0.9150327 & 0.2797488 \\
RF & 153 & 0.0000043 & 0.1420808 & 0.0159055 & 0.0179181 \\
\hline
\end{tabular}

\subsection{Regression Models}

In this section, we carry out our econometric analysis. We investigate the effects of foreign ownership on R\&D investment.

Table 2 uses Pearson related coefficients validity test to test the self-relationship among the independent variables. The upper listed the Pearson related coefficients, and the bottom listed the significance. 
Table 2. Pearson correlation matrix

\begin{tabular}{|c|c|c|c|c|c|c|}
\hline & RDS & FO & $\mathrm{H}$ & SIZE & ALR & IND \\
\hline RDS & 1 & & & & & \\
\hline \multirow[t]{2}{*}{$\mathrm{FO}$} & 0.0460714 & 1 & & & & \\
\hline & 0.5717349 & & & & & \\
\hline \multirow[t]{2}{*}{$\mathrm{H}$} & -0.0704229 & 0.2643192 & 1 & & & \\
\hline & 0.387031 & 0.0009615 & & & & \\
\hline \multirow[t]{2}{*}{$\begin{array}{c}\text { SIZ } \\
\text { E }\end{array}$} & -0.0733311 & -0.2169161 & 0.1914579 & 1 & & \\
\hline & 0.3676786 & 0.007076 & 0.0177517 & & & \\
\hline \multirow[t]{2}{*}{ ALR } & -0.2580649 & -0.0661728 & 0.0667341 & 0.4682916 & 1 & \\
\hline & 0.001279 & 0.416395 & 0.412444 & $1.034 \mathrm{E}-09$ & & \\
\hline \multirow[t]{2}{*}{ IND } & 0.0289384 & -0.0627891 & 0.1022412 & -0.0853631 & -0.2174359 & 1 \\
\hline & 0.7225246 & 0.4406769 & 0.2085435 & 0.2941134 & 0.0069369 & \\
\hline
\end{tabular}

Notes: the Pearson related coefficients are listed on the upper and the significance is listed on the bottom.

Further study shows that there is no multicollinearity between variables, and then we can get the regression model, listed as follows:

$$
\mathrm{RDS}=0.008+0.019 \mathrm{FO}+0.008 \mathrm{SIZE}-0.093 \mathrm{ALR}-0.039 \mathrm{H}-0.002 \mathrm{IND}
$$

From the regression model, we can know foreign ownership and corporate $R \& D$ investment do exist positive relationship, which indicates that the introduction of foreign investors can increase the R\&D expenses to enhance innovation. Therefore, assumption is proven. Some other interesting findings are listed as follows:

There is a positive relationship between R\&D investment and firm size; the ratio of debt to total assets, the proportion of the top five shareholders, and the location will negatively affect the R\&D investment

\section{Conclusion and Suggestion}

This paper empirically studies the impacts of the foreign investment on R\&D investment. We find that foreign investment can positively improve the R\&D investment, but not significantly. And further study shows that foreign ownership negatively affects the enterprise performance.

From the conclusion, we know that the introduction of foreign investors can positively improve the R\&D investment, but this impact is not great. Therefore, it is important for enterprises to understand that it is more reliable to increase R\&D intensity by their own to enhance innovation, rather than rely on external forces. But the introduction of foreign investors indeed improves the innovation of SMEs, which is good but not the most important.

\section{References}

Chen, L. (2011). Foreign Ownership and Corporate Performance. Jinan University, Guangzhou.

Claessens, S., Djankow, S., \& Lang, L. (2000). The Separation of Ownership and Control in East Asian $\begin{array}{llll}\text { Corporation. Journal of Financial } & \text { Economics, }\end{array}$ http://dx.doi.org/10.1016/S0304-405X(00)00067-2

Dechow, P. M., \& Sloan, P. G. (1991). Execuive Incentives and the Horizon Problem: An Empirical Investigation. Journal of Accounting and Economics, 14(1), 51-89. http://dx.doi.org/10.1016/0167-718 (91)90058-S

Jensen, M. C., \& Mechling, W. H. (1976). Theory of the Firm: Managerial Behavior, Agency Cost and Ownership Structure. Journal of Financial Economics, 3(4), 305-360. http://dx.doi:10.1016/0304-405V(76)90026-X

Joon, K., Jiyeon, E. K., Wi, S. K., \& Suk, J. B. (2010). Foreign Investors and Corporate Governance in Korea. Pacific Basin Finance Journal, 18, 390-420. 
Lei, J. (2012). The Analysis of the Impact of the Introduction of Foreign investors on Ownership Structure and Corporate Performance of Private Listed Corporate. Fudan University, Shanghai.

Manoranjan, P. (2007). Insider Ownership and Firm Value: Evidence from Indian Corporate Sector. Economics and Political Weekly, 21, 1459-1467.

Megginson, W. L. (2005). The Economics of Bank Privatization. Journal of Banking and Finance, 29, 1931-1980.

Megginson, W. L., \& Netter, J. M. (2001). From State to Market: A Survey of Empirical Studies on Privatization. Journal of Economic Literature, 39, 321-390.

Qu, L. Q., \& Wang, H. L. (2007). Whether Foreign Investment can Enhance Corporate Value? An empirical Analysis Based on Listed Companies. Shanghai Finance, 1, 51-54.

Shieifer, A., \& Vishny, R. W. (1986). Large Shareholds and Corporate Control. Journal of Political Economy, 57, 401-488.

Shieifer, A., \& Vishny, R. W. (1997). The Limits of Arbitrage. Journal of Finance, 52, 35-55.

Sun, Q., \& Tong, Wilson H. S. (2003). China Share Issue Privatization: the Extent of Its Success. Journal of Financial Economics, 70, 183-222.

Wang, Y. M. (2009). Research on the Value of Foreign Strategic Investors. China Soft Science, 3, 138-143.

Yao, Q., Xu, M., Jiang, W. F., \& Zhang, Y. (2014). An exploratory study on technological innovation of agriculture science and technology enterprises in china. iBusiness, 6, 101-108. http://dx.doi.org/10.4236/ib.2014.63011

Ye, D. Z., \& Liu, S. B. (2015). Foreign Ownership and Technology Innovation. Study of Institutional Economics, 2, 126-142.

Zhang, B. H. (2007). An Empirical Study of the Impact of Foreign Mergers and Acquisitions on the Firm Performance. Special Zone Economy, 109-111.

\section{Copyrights}

Copyright for this article is retained by the author(s), with first publication rights granted to the journal.

This is an open-access article distributed under the terms and conditions of the Creative Commons Attribution license (http://creativecommons.org/licenses/by/4.0/). 